Justyna Fronczak

Uniwersytet w Biatymstoku

\title{
STALKING Z PERSPEKTYWY INTERDYSCYPLINARNEJ
}

\section{Wstęp}

Etymologia słowa „stalking” związana jest z pojęciem odnoszącym się do żargonu myśliwskiego. „To stalk” należy tłumaczyć jako skradanie się, chodzenie, skrywanie się, a są to określenia czynności wykonywanych przez kłusownika, który poluje na zwierzynę. ${ }^{1}$ Można odnaleźć w tym pewną analogię do zachowania stalkera, który nęka swoją ofiarę.

W 1989 roku po raz pierwszy użyto słowa „stalker” na określenie sprawcy prześladowania. Media informowały wówczas o przypadkach stalkingu dotyczących gwiazd showbiznesu, m.in. o zamordowaniu aktorki Rebecci Scheaffer przez chorego psychicznie fana. Kilka lat wcześniej ofiarą stalkera stał się John Lennon, który został zastrzelony przez swego ,psychofana”. ${ }^{2}$ Sprawcami stalkingu w tamtym okresie byli przede wszystkim chorzy, posiadający pewne zaburzenia psychiczne, fani. Zaczęto wówczas postrzegać stalking jako zapowiedź przemocy, której sprawca może w przyszłości użyć wobec swojej ofiary. ${ }^{3}$

Aktorka Jodie Foster była przez długi okres ofiarą stalkingu. Jej prześladowcą okazał się John Hinckley. Z powodu odrzucenia przez gwiazdę, mężczyzna dokonał zamachu na prezydenta Ronalda Regana. Przed atakiem wysłał Foster list, w którym napisał: „Będziesz ze mnie dumna. Miliony Amerykanów będą mnie - będą nas kochać". ${ }^{4}$ Nękanie aktorki rozpoczęło się od emisji filmu, w którym Jodie Foster wcieliła się $\mathrm{w}$ rolę prostytutki. Sprawca uroił sobie, iż w przeszłości był z nią związany, z racji czego musiał jej pomóc, by przestała się prostytuować. ${ }^{5}$

Wielki słownik polsko-angielski, Oxford 2002, s. 1138.

Uzasadnienie projektu ustawy - o zmianie ustawy - Kodeks Karny, druk nr 3553, strona internetowa, http://ww2.

senat.pl/k7/dok/sejm/072/3553.pdf, dostęp dn. 17.11.2012 r., s. 1

P. Mullen, M. Pathe, R. Purcell, Stalkers and their victims, Cambridge University Press 2009, s. 12.

B. Hołyst, Psychologia kryminalistyczna, Warszawa 2009, s. 736.

W. Staszewski, Stalking. To nie miłość, to prześladowanie, strona internetowa, http://www.wysokieobcasy.pl/wys okieobcasy/1,96951,6948572,Stalking_To_nie_milosc_to_przesladowanie.html, dostęp dn. 17.11.2012 r. 
Poza medialnymi prześladowaniami celebrytów, warto przypomnieć także sprawę morderstwa Miss Polski z 1991 r. - Agnieszki Kotlarskiej, która w 1996 r. zginęła na ulicy z rąk swego prześladowcy. Stalker zamordował swoją ofiarę, kilkakrotnie raniąc ją nożem. Sprawca przez cały okres nękania twierdził, iż jego ofiara była księżniczką, on zaś jej krasnoludkiem. ${ }^{6}$

\section{Pojęcie, istota i charakterystyka stalkingu}

Zgodnie z definicją kliniczną, stalking należy rozpatrywać w kontekście zespołu powtarzających się i uporczywych zachowań, mających na celu wymuszenie na drugiej osobie niechcianego kontaktu. Zaznaczyć należy, iż stalking nie powinien być definiowany poprzez intencje prześladowcy (stalkera), lecz poprzez skutki, wywoływane przez te zachowania $u$ ofiary. ${ }^{7}$ Natomiast na gruncie psychologii, stalking traktowany jest jako rodzaj uzależnienia, w którym środkiem uzależniającym jest drugi człowiek (ofiara). ${ }^{8}$

J.R. Meloy i S. Gothard definiowali stalking jako niecodzienny i długotrwały zespół zachowań, które naruszają prywatność danej jednostki, a tym samym wzbudzają w niej poczucie lęku oraz wywołują stres. Zgodnie z tym rozumieniem należy przyjąć, iż muszą wystąpić co najmniej dwa incydenty spełniające powyższe warunki. ${ }^{9}$ Jednak $\mathrm{w}$ tej definicji pojawia się problem $\mathrm{z}$ rozumieniem zwrotu „niecodzienności” zachowań, gdyż jest to aspekt dość subiektywny. Oto przykład: mężczyzna, który codziennie, przez cały okres trwania małżeństwa, dawał swojej żonie kwiaty, może nie zostać uznany za stalkera, jeżeli po rozwodzie będzie nagminnie wysyłać byłej małżonce różnego rodzaju niechciane prezenty.

Stalking można podzielić na trzy rodzaje, uwzględniając stopień zażyłości pomiędzy ofiarą a sprawcą. Pierwszy z nich After-intimate - relationship - stalking występuje najczęściej, gdyż sprawca i ofiara dobrze się znają: byli w przeszłości parą, kolegami, sąsiadami, przyjaciółmi. Drugi rodzaj, zwany Acquaintance - Stalking, występuje przy mniejszym stopniu zażyłości oraz znajomości. Ofiara i sprawca mogli kiedyś przypadkowo się poznać lub spotkać, lecz nie nawiązali bliższego kontaktu. Trzeci rodzaj, Stranger - Stalking, dotyka najczęściej ludzi sławnych, gdyż w tym przypadku ofiara nigdy nie poznała osobiście sprawcy. ${ }^{10}$

6 D. Woźniakowska-Fajst, Prawne możliwości walki ze zjawiskiem stalkingu - czy w prawie polskim potrzebna jest penalizacja prześladowania, „Archiwum Kryminologii” 2009, tom XXXI, s. 174.

7 M. Pathe, Surviving stalking, Cambridge 2002, s. 8.

8 W. Woźniak, M. Lattanzi, Stalking - między przemocą a uzależnieniem, Konstantynów Łódzki-Kutno 2010, s. 12.

9 P. Mullen, M. Pathe, R. Purcell, Stalkers..., op. cit., s. 3.

10 A. Chlebowska, P. Nalewajko, Stalking - zarys problemu oraz analiza rozwiązań ustawodawcy niemieckiego, austriackiego, polskiego, „Prokurator” 2010/2011, nr 4(44)/1(45), s. 32. 
Podziału stalkingu można dokonać także ze względu na rodzaj czynności, które są podejmowane przez sprawcę. Wówczas za kryterium rozróżniające przyjmuje się zachowania stanowiące naruszenie przestrzeni prywatnej ofiary, z wykorzystaniem środków przekazu i kontaktu, w tym nowoczesnych technik informatycznych i telekomunikacyjnych, jak też podejmowanie działań wobec rodziny ofiary i jej przyjaciół. ${ }^{11}$ Zachowania stalkera mogą być zarówno bezpośrednie, gdy sprawca samodzielnie nęka swoją ofiarę, jak i pośrednie - przy korzystaniu z pomocy innych osób lub narzędzi, które pozwalają zachować anonimowość.

Typowym zachowaniem stalkera jest śledzenie ofiary i podążanie w miejsca uczęszczane przez nią. Niektórzy sprawcy chcą być w ten sposób zauważeni i rozpoznani, podczas gdy inni wolą pozostać w ukryciu i obserwować ofiarę $\mathrm{z}$ daleka. Takie zachowanie często połączone jest $\mathrm{z}$ roznoszeniem fałszywych plotek na temat ofiary, by dzięki temu zniszczyć jej reputację. ${ }^{12}$ Działanie to ma na celu także doprowadzenie do odwrócenia się od ofiary jej najbliższego otoczenia, sprawca może pokazać wtedy swoją wierność i oddanie.

Sprawca, chcąc wzbudzić u ofiary niepokój, może wysyłać lub zostawiać pod jej domem różnego rodzaju niechciane prezenty. Wyobraźnia stalkera przy wyborze takich przedmiotów jest nieograniczona. Mogą to być zarówno typowe prezenty (takie jak czekoladki, maskotki, książki, biżuteria), jak i rzeczy dziwne, np. słoik z moczem, zamrożony kurczak czy nawet makabryczne podarunki (m.in. zdechłe zwierzęta, klepsydry). Nie tylko same prezenty mogą być niepokojące z perspektywy ofiary, lecz także sposób ich dostarczenia, bowiem sprawca może wysyłać jeden przedmiot dziennie lub dokonywać przesyłek hurtowo. ${ }^{13}$

Zachowania prześladowcy mogą być powiązane z wykorzystaniem technologii, np. uporczywe dzwonienie oraz wysyłanie SMS-ów do ofiary. Nieograniczone możliwości stwarza współcześnie Internet, a wykorzystanie tej formy w celu nękania kogoś uważa się za cyberstalking, czyli stalking w przestrzeni wirtualnej. Wskazuje się tutaj na różne postacie zachowań, a mianowicie: wysyłanie dużej liczby e-maili na konto pocztowe ofiary wbrew jej woli, uniemożliwienie korzystania ze skrzynki pocztowej, a także podszywanie się pod ofiarę na różnego rodzaju czatach, portalach społecznościowych, forach. ${ }^{14}$

Sprawcy mogą dokonywać także innych czynności, by uprzykrzyć życie ofierze. Mogą zamawiać różnego rodzaju produkty i usługi w imieniu ofiary. Przykładem może być zamówienie pizzy, ale także wezwanie straży pożarnej, ambulansu na

\footnotetext{
11 M. Królikowski, Opinia dotycząca zasadności kryminalizacji stalkingu oraz konstrukcji ewentualnego typu czynu zabronionego, http://bip.ms.gov.pl/pl/dzialalnosc/komisje-kodyfikacyjne/komisja-kodyfikacyjna-prawa-karnego/ opinie-komisji-kodyfikacyjnej-prawa-karnego/, dostęp dn. 16.11.2012 r., s. 1. 
adres ofiary. W literaturze amerykańskiej dodatkowo podaje się, iż powszechnym sposobem działania stalkera jest inicjowanie fałszywych czynności prawnych. Dzięki temu sprawcy udaje się sprowadzić do sądu ofiarę w celu kontaktu z nią ${ }^{15}$

\section{Motywy i konsekwencje stalkingu}

Przyczyn stalkingu należy upatrywać w kontekście jednostkowym oraz w szerszej perspektywie społeczno-kulturowej. Determinantem zachowań prześladowczych są zaburzenia osobowości: graniczne (borderline) oraz narcystyczne. Pierwsze $\mathrm{z}$ nich wiążą się z nadmiernym strachem przed porzuceniem. Stalkerzy posiadający ten typ zaburzeń mają przekonanie, iż same są ofiarami, choć to one prześladują inne osoby. ${ }^{16}$ Uzasadnieniem takiego zachowania sprawcy może być to, iż osoby te posiadają niską samoocenę, a wszelkiego rodzaju odrzucenie przez innych ludzi powoduje u nich poczucie poniżenia. Chcąc zrekompensować sobie to uczucie za wszelką cenę dążą do przejęcia kontroli nad osobą, która ich odrzuciła. ${ }^{17}$

Drugim rodzajem zaburzenia dominującego u stalkerów jest narcystyczne zaburzenie osobowości. Osoby takie lubią kontrolować swoje życie, co przekłada się także na życie innych osób, np. partnerów. Wszelkie odrzucenie powoduje stan urojenia, gdyż osoby z narcystycznym zaburzeniem osobowości próbują przełożyć swój świat fantazji na świat rzeczywisty. ${ }^{18}$

Jednak nie wszyscy sprawcy stalkingu mają zaburzenia osobowości, nawet jeśli ich zachowania są typowe dla narcyzmu czy osobowości borderline. Mogą one bowiem być po prostu wynikiem ukształtowania się nieprawidłowych relacji z matką i ojcem, ale bez rozwinięcia się zaburzeń osobowości. Zjawisko to występuje u osób, które w dzieciństwie nie były otaczane właściwą opieką fizyczną oraz wsparciem emocjonalnym ze strony rodziców. Dziecko przystosowało się w związku z tym do świata, w którym zachowania opiekunów nie są przewidywalne i stabilne. W ten sposób wytworzyło swój własny świat, w którym jedynym celem było odzyskanie uwagi i zainteresowania rodziców. W późniejszym wieku, tym samym celom służyło manipulowanie rodzicami, m.in. poprzez szantaże, groźby i autodestrukcję. ${ }^{19}$ Działania sprawców stalkingu mogą wynikać także z sytuacji, w jakiej się znaleźli. Determinująco mogły bowiem zadziałać takie czynniki, jak: samotność, izolacja, a także dorastanie w środowisku patologicznym. ${ }^{20}$

15 M. Pathe, Surviving stalking, op. cit., s. 11.

16 W. Woźniak, M. Lattanzi, Stalking..., op. cit., s. 27-28.

17 J. Skarżyńska - Sernaglia, Stalking w Polsce - występowanie i charakterystyka zjawiska, strona internetowa, http://psychologia.net.pl/artykul.php?level=415, dostęp dn. 18.11.2012 r.

18 D. Janus, „Nie mam problemów”, czyli o zaburzeniach osobowości, strona internetowa, http://www.psychologia. net.pl/artykul.php?level=389, dostęp dn. 18.11.2012 r.

19 D. Piotrowicz, Chorobliwa miłość, „Psychologia w teatrze życia” 2009, nr 1, s. 5.

20 M. Pathe, Surviving stalking, op. cit., s. 19. 
Z punktu widzenia socjologicznego, występowanie zjawiska stalkingu jest zarówno przyczyną, jak i skutkiem braku zaufania w społeczeństwie. Genezy stalkingu można bowiem upatrywać w konsekwencjach wzmożonej urbanizacji, która zmusiła ludzi do życia wśród nieznajomych. Egzystując w słabej integracji z najbliższym otoczeniem, jednostka staje się bardziej wrażliwa i podejrzliwa w stosunku do innych osób. W takiej sytuacji nieznani sąsiedzi są dużo częściej postrzegani jako potencjalne zagrożenie dla prywatności. ${ }^{21}$

Kolejną socjokulturową przyczynę występowania stalkingu wyjaśnia dość kontrowersyjny pogląd, pojawiający się $\mathrm{w}$ literaturze, który wiąże istnienie prześladowania kobiet $\mathrm{z}$ ich emancypacją. Zastąpienie dawnego systemu patriarchalnego swobodą decydowania kobiet o sobie mogło wywołać frustrację mężczyzn, którzy - nie mogąc pogodzić się z wyzwoleniem kobiet - chcą nadal mieć kontrolę nad ich życiem. Stąd też pojawiające się zachowania prześladowcze. Zatem emancypacja kobiet, a także ich wzmożona obecność w życiu publicznym, wiąże się z ich większą podatnością na bycie ofiarą niechcianego zalotnika. ${ }^{22}$

Na gruncie badań przeprowadzonych pod kierownictwem prof. dr. hab. Andrzeja Siemaszko, odnoszących się m.in. do skutków stalkingu z perspektywy ofiary wskazano, że 70\% osób doświadczyło wskutek nękania negatywnych konsekwencji $\mathrm{w}$ sferze psychicznej oraz fizycznej. Aż $50 \%$ ofiar zmagało się $\mathrm{z}$ różnego rodzaju problemami emocjonalnymi lub innymi natury psychicznej. Ponad $30 \%$ pokrzywdzonych stwierdziło, iż obawia się wyjścia z domu, a $25 \%$ zadeklarowało objawy agresji oraz rozkojarzenia. Niewątpliwie nagromadzenie negatywnych emocji spowodowanych nękaniem przyczynia się do powstania poważnych konsekwencji, które oddziałują na psychikę człowieka. Widać to zwłaszcza w tym, iż co dziewiąta ofiara miała myśli lub próby samobójcze. Ponad $40 \%$ osób wskazało na zaburzenia łaknienia, a $20 \%$ zadeklarowało występowanie innych objawów fizjologicznych. Prawie $20 \%$ ofiar musiało ponieść konsekwencje w postaci zmiany pracy lub jej utraty, natomiast $12 \%$ pokrzywdzonych było zmuszonych do zmiany miejsca zamieszkania. Na skutek stalkingu wysoki odsetek osób zaczął nadmiernie spożywać używki, a mianowicie $35 \%$ ofiar paliło papierosy, $11 \%$ spożywało alkohol, a $25 \%$ zażywało leki uspokajające lub brało narkotyki. ${ }^{23}$

21 P. Mullen, M. Pathe, R. Purcell, Stalkers..., op. cit, s. 12-14.

22 Ibidem, s. 12-14.

23 B. Gruszczyńska, M. Marczewski, P. Ostaszewski, A. Siemaszko, D. Woźniakowska-Fajst, Stalking w Polsce. Rozmiary - Formy - Skutki, [w:] Stosowanie prawa. Księga jubileuszowa z okazji XX-lecia Instytutu Wymiaru Sprawiedliwości, A. Siemaszko (red.), Warszawa 2011, s. 840-842. 


\section{Profil sprawców stalkingu}

Uwzględniając różne czynniki uzasadniające występowanie stalkingu, stworzony został katalog profili sprawców stalkingu. Pierwszym $\mathrm{z}$ nich jest sylwetka tzw. „odrzuconego” (rejected), m.in. przez małżonka, partnera. Jego działania podyktowane są tym, iż druga strona chce zakończyć dany związek. Stalker początkowo próbuje załagodzić sytuację, dążąc do osiągnięcia porozumienia lub wymierzenia tej osobie „nieszkodliwej kary”. W większości przypadków natura związku pomiędzy stalkerem typu rejected a ofiarą opierała się na relacjach intymnych. Mógł to jednak być także inny rodzaj związku, w który odrzucony partner zainwestował pokłady emocjonalne. Przykładem może być relacja z bliskim przyjacielem, współpracownikiem, członkiem rodziny, a także związki, takie jak: nauczyciel - uczeń, lekarz - pacjent. Stalker motywowany jest przez żal oraz uczucie niesprawiedliwości i upokorzenia. Niektórzy sprawcy zdają sobie sprawę, iż utracony związek jest niezastąpiony. Wiedzą, że prześladowanie nie zjednoczy ich ponownie ani nie uratuje relacji, ale - w przekonaniu stalkera - utrzyma ich w kontakcie. Sprawcom, którzy nie mogą pogodzić się z rozstaniem, stalking będzie zastępować związek i stworzy złudną nadzieję bliskości. Zazwyczaj „odrzuceni” stalkerzy sami siebie uważają za ofiarę, a prześladowanie dokonywane z ich strony tłumaczą jako prowokację. Należy dodać, iż ,odrzuceni” stosują największe spectrum zachowań składających się na stalking, a determinacja uprzykrzenia życia eks-partnerowi będzie wyrażała się $\mathrm{w}$ zachowaniach naruszających prywatność ofiary: śledzenia jej, zbliżania się, wysyłania dużej liczby listów i sms-ów. ${ }^{24}$

Kolejny profil sprawcy stalkingu nazywany jest „poszukiwaczem intymności” (intimacy seeker). Głównym celem tego typu stalkerów jest nawiązanie nowej bliskiej relacji lub podtrzymanie dawnej znajomości, istniejącej kiedyś pomiędzy ofiarą a sprawcą. W dążeniu do swego celu stalkerzy idealizują swoją ofiarę, przypisując jej cechy, które zdaniem sprawcy są najlepsze, choć nie zawsze zgodne z rzeczywistością. Dodatkowo „poszukiwacze intymności” są wytrwali w swoich dążeniach, gdyż nie zniechęca ich negatywna reakcja ofiary. Ten rodzaj stalkerów to często osoby samotne, pozbawione doświadczenia intymności. Zarówno sam akt stalkingu, jak i nadzieja na związek z ofiarą zdają się być swoistym lekiem na ich samotność. Należy zaznaczyć jednak, iż nie wszystkie osoby samotne stają się prześladowcami, a zatem uczucie izolacji odczuwane przez jednostkę nie może być przyczyną objawiania się zachowań związanych ze stalkingiem. Niewątpliwie symptomem tego typu działań jest zaburzenie osobowości: stalker tworzy imaginację związku z osobą, która odrzuca jego starania. Związane jest to z interpretowaniem 
przez stalkera negatywnych reakcji ofiary jako reakcji pozytywnych i zachęcających do dalszego działania. ${ }^{25}$

Erotoman to kolejny przykład profilu stalkera, który jest zbliżony do poprzedniego, pod względem zachowania prezentowanego przez sprawcę. Wynika ono jednak bardziej z choroby psychicznej, np. schizofrenii, pewnego rodzaju manii, a nawet defektów mózgu. Erotoman uważa, że jego miłość do ofiary jest odwzajemniona. Ten rodzaj sprawców wybiera sobie na ofiarę najczęściej osoby atrakcyjne fizycznie i o wyższym statusie społecznym niż on sam. Niektórzy erotomani nie żyją wyobrażeniami czy imaginacją przeżytej relacji intymnej z osobą, ale dopiero jej poszukują, a przykładem tego jest stalker Jodie Foster. Warto dodać, iż ci prześladowcy przejawiają determinację podobną do „odrzuconych”, gdyż związek z ofiarą stanowi cel ich życia. Część z nich będzie zabiegać o uwagę ofiary na przestrzeni kilku, a nawet kilkunastu lat. ${ }^{26}$ Jednak zdaniem B. Hołysta połączenie erotomanii ze stalkingiem nie jest zasadne, z racji braku w nękaniu problemu medycznego. Nie należy bowiem rozpatrywać stalkingu z perspektywy wszelkiego rodzaju zaburzeń mających podłoże psychiczne, gdyż przyczynia się to do braku odpowiedzialności sprawcy za swoje działania, a także zmienia obraz tego prześladowania i nie wyjaśnia istoty rzeczy. ${ }^{27}$

Następny profil stalkera to „nieudolny adorator” (incompetent suitor), będący w rzeczywistości pseudoadoratorem, który zabiega o obiekt uczuć w nieodpowiedni sposób, co w konsekwencji daje efekt przeciwny do zamierzonego. Stalkerzy w tej grupie to często osoby ze słabymi zdolnościami w nawiązywaniu bliskich relacji. Kieruje nimi silne uczucie chęci stworzenia związku z osobą, którą uznali za interesującą, bez względu na jej uczucia. Przeświadczenie, iż dana relacja im się należy, czyni ich niestrudzonymi w dążeniach. Ich preferowany sposób komunikacji to kontakt bezpośredni. Dodatkowo zauważono, iż „nieudolnych adoratorów” można podzielić na dwie grupy: osoby widzące w nękaniu cel swego życia, bez względu na powzięte $w$ tym zakresie środki oraz osoby zabiegające o zgodę ofiary na randkę czy intymne spotkanie. ${ }^{28}$

Kolejna charakterystyka sprawców stalkingu obejmuje tzw. osoby „urażone” (resentful). W działaniu tych stalkerów widoczna jest chęć zemsty na ofierze i wzbudzenie u niej maksymalnego strachu. Motywacja sprawcy do wyrządzenia krzywdy ofierze może wybiegać poza ramy nienawiści względem jednostki i odnosić się do nienawiści wobec systemu, korporacji, większej grupy. Nie będzie zatem dziwił fakt, że stalker posiadający tak wielką chęć zemsty nie dostrzega tego, że obarcza winą bezbronne osoby. W rzeczywistości jest bowiem odwrotnie,

M. Pathe, Surviving stalking, op. cit., s. 22-23.

Ibidem, s. 23-24.

B. Hołyst, Psychologia..., op. cit., s. 735.

M. Pathe, Surviving stalking, op. cit, s. 25. 
a mianowicie stalker widzi siebie jako ofiarę. „Urażeni” prześladowcy posługują się najczęściej groźbami, choć rzadko je spełniają - w obawie przed konsekwencjami prawnymi. ${ }^{29}$

Ostatnią grupę sprawców stalkingu stanowią „drapieżni” stalkerzy (predatory), którzy - zgodnie z amerykańskimi badaniami - stanowią 5\% wszystkich stalkerów. Pomimo ich stosunkowo małej liczebności, to właśnie ich działania są najczęściej przedstawiane przez media. Motywem nękania są pobudki seksualne, a sam stalking jest sposobem na poczucie przewagi nad ofiarą. Stwierdza się również, iż często nękanie daje stalkerowi satysfakcję seksualną, np. poczucie podniecenia podczas telefonowania do ofiary, a w niektórych wypadkach stalking może mieć charakter zapowiedzi ewentualnej napaści seksualnej. Większość „drapieżnych” stalkerów cierpi na zaburzenia seksualne oraz ma za sobą procesy o napaści seksualne. ${ }^{30}$

\section{Prawnokarna problematyka stalkingu}

$\mathrm{Na}$ gruncie prawa polskiego, sposobem walki ze stalkingiem od $2011 \mathrm{r}$. jest art. 190a k.k., którego $§ 1$ brzmi: „Kto przez uporczywe nękanie innej osoby lub osoby jej najbliższej wzbudza u niej uzasadnione okolicznościami poczucie zagrożenia lub istotnie narusza jej prywatność, podlega karze pozbawienia wolności do 3 lat". ${ }^{31}$ Został on wprowadzony ustawą z dnia 25 lutego 2011 r. o zmianie ustawy - Kodeks karny. M. Filar zauważył, iż taka budowa przepisu wprowadza wiele wątpliwości i nie daje konkretnej odpowiedzi, co tak naprawdę jest penalizowane, gdyż jego zdaniem art. 190a k.k. zawiera wiele niedookreślonych i nieostrych pojęć, które dodatkowo są wyjaśniane prze inne niejasne pojęcia. ${ }^{32}$ Wskazano również, iż intencją ustawodawcy wprowadzającego art. 190a k.k. było spenalizowanie czynu zabronionego, dającego się określić jedynie za pomocą kategorii ocennych, co powodować będzie konieczność ciągłego odwoływania się do doktryny oraz orzecznictwa. Zarzuca się wobec tego ustawodawcy nieprzestrzeganie normatywnej zasady określoności czynu zabronionego przez ustawę. ${ }^{33}$

Jednym ze znamion przestępstwa stalkingu jest „uporczywe nękanie”. Zdaniem ustawodawcy wyrażonym w uzasadnieniu do projektu tej ustawy, takie sformułowanie $\mathrm{w}$ pełni oddaje sens postępowania stalkera, gdyż wskazuje na

Kodeks karny - ustawa z dnia 6 czerwca 1997 r. (Dz.U. Nr 88, poz. 553 ze zm.).

M. Budyn-Kulik, Kodeks karny. Komentarz do zmian wprowadzonych ustawą z dnia 25 lutego 2011 r. o zmianie ustawy - Kodeks karny, wersja online, Lex., pkt 17.

33 J. Długosz, O zasadności kryminalizacji tzw. stalkingu, [w:] Tożsamość polskiego prawa karnego, S. Pikulski, M. Romańczuk-Grocka, B. Orłowska-Zielińska (red.), Olsztyn 2011, s. 253. 
powtarzalność zachowań, które dręczą ofiarę, przez co ograniczają jej wolność. ${ }^{34}$ Jednak pojawiały się głosy sprzeciwu przed umieszczeniem przymiotnika „uporczywe”, gdyż samo określenie ,nękać” wskazuje na szereg zachowań, a dodatkowe wymagania ustawowe uniemożliwiać będą stosowanie art. 190a k.k. w praktyce. ${ }^{35}$ Utrudnione byłoby jednak liczebnikowe wskazanie liczby czynów popełnianych przez stalkera, bowiem sprawca może działać z dużą intensywnością, co uniemożliwia wyodrębnienie jego poszczególnych działań.

Przez „uzasadnione okolicznościami poczucie zagrożenia” należy rozumieć: „brak poczucia bezpieczeństwa u pokrzywdzonego, wynikający z wielokrotnych, natarczywych i nawracających zachowań podjętych przez nękającego". ${ }^{36}$ M. Mozgawa zauważa, iż to znamię zostanie wypełnione w sytuacji, gdy ofiara nękania zacznie odczuwać lęk i podejmie działania mające na celu jego zminimalizowanie, wskutek zmiany relacji z innymi osobami lub szukania pomocy u lekarza, jak również w przypadku, gdy nie występuje u ofiary stalkingu poczucie zagrożenia, np. z powodu bycia tzw. osobą silną psychicznie. ${ }^{37}$ Ustawodawca bowiem nie określa, jak bardzo ofiara powinna czuć się zagrożona, gdyż mogą to być zarówno stany zaniepokojenia, jak i przerażenia. ${ }^{38}$ Wskazywana w tej kwestii konieczność zasięgnięcia opinii „wzorcowego obywatela”, a więc policji i prokuratury - na etapie postępowania przygotowawczego - oraz sądu - na etapie postępowania sądowego - może napotykać wiele trudności. „Wzorcowy obywatel” nie znajduje się w tej samej sytuacji co ofiara, a więc nie może ocenić, czy zachowanie stalkera może budzić poczucie zagrożenia, czy nie. Stąd wnioskować można, iż zanim nie ukształtuje się jednolita linia orzecznicza, większość wpływających do sądu spraw będzie rozstrzygana na korzyść pokrzywdzonego.

Typem podstawowym przestępstwa stalkingu penalizowanym w art. 190a $\S 2$ k.k. jest natomiast podszywanie się pod inną osobę, wykorzystanie jej wizerunku lub innych danych osobowych w celu wyrządzenia jej szkody majątkowej lub osobistej. Zdaniem ustawodawcy konieczne było umieszczenie tego typu negatywnych zachowań w odrębnym paragrafie, ponieważ np. wykorzystanie danych osobowych może być działaniem jednorazowym, w odróżnieniu od wielokrotnego, uporczywego nękania. ${ }^{39}$ Sprawca stalkingu może wykorzystać cudzy wizerunek lub dane osobowe swojej ofiary, w celu jej prześladowania, co wiąże się z nieuprawnionym korzystaniem z nich. A. Sakowicz zauważa zasadność takiej

34 Uzasadnienie projektu ustawy o zmianie ustawy - Kodeks karny, druk 3553, strona internetowa http://ww2.senat. $\mathrm{pl} / \mathrm{k} 7 / \mathrm{dok} / \mathrm{sejm} / 072 / 3553 . p d f$, dostęp dn. 17.11.2012 r., s. 6.

35 M. Mozgawa, Opinia w sprawie projektu ustawy o zmianie ustawy - Kodeks karny, druk sejmowy nr 3553, opinia dostępna na stronie internetowej Sejmu, s. 6.

Uzasadnienie..., op. cit., s. 7-8.

M. Mozgawa, Opinia..., op. cit., s. 7.

M. Budyn-Kulik, Kodeks karny..., op. cit., pkt 28.

Uzasadnienie..., op. cit., s. 10. 
regulacji na gruncie prawa karnego, gdyż konieczne jest zapewnienie jak najszerszej ochrony wizerunku. ${ }^{40}$ Przed wprowadzeniem art. 190a $\S 2$ k.k. wizerunek podlegał jedynie ochronie na kanwie prawa cywilnego, na podstawie przepisów dotyczących ochrony dóbr osobistych. Dodatkowo art. 81 ustawy o prawie autorskim i prawach pokrewnych z 4 lutego 1994 r. zapewniał ochronę wizerunku przed bezprawnym jego rozpowszechnianiem. ${ }^{41}$

Przestępstwo przywłaszczenia tożsamości zagrożone jest taką samą karą jak przestępstwo z art. 190a $\S 1$ k.k., a mianowicie karze pozbawienia wolności do 3 lat. Natomiast ustawowa różnica w wymiarze kary występuje w przypadku typu kwalifikowanego uregulowanego w art. 190a $§ 3$ k.k., gdyż zagrożenie karą wynosi w tym przypadku od roku do 10 lat pozbawienia wolności. Ustawodawca przewidział takie granice sankcji, jeżeli następstwem czynu określonego w $\S 1$ i $~ 2$ jest targnięcie się pokrzywdzonego na własne życie. Uzasadnił to tym, iż „granice ustawowego zagrożenia zostały określone na tym poziomie dla zapewnienia pełnej spójności z innymi rozwiązaniami kodeksowymi, w szczególności do sankcji przewidzianej w art. 151 k.k., która za doprowadzenie do targnięcia się na własne życie za pośrednictwem namowy lub udzielenia pomocy przewiduje odpowiedzialność karną w granicach od 3 miesięcy do 5 lat pozbawienia wolności". ${ }^{42}$

Należy także wskazać, iż przestępstwa z art. 190a $§ 1$ i $§ 2$ k.k. są ścigane na wniosek pokrzywdzonego. Wynika to $\mathrm{z}$ faktu, iż przestępstwa te są czynami godzącymi w sferę wolności i intymności człowieka. ${ }^{43}$ Natomiast art. 190a $§ 3$ k.k. przewiduje tryb ścigania publicznoskargowy z urzędu, z racji większej wartości przedmiotu ochrony w tym wypadku, a mianowicie zdrowia i życia człowieka. ${ }^{44}$

\section{Podsumowanie}

Penalizacja stalkingu i wprowadzenie art. 190a k.k. ma swoich zwolenników i przeciwników. Podnosi się z jednej strony, iż dotychczasowe sposoby karania stalkerów - na podstawie innych przepisów kodeksu karnego i kodeksu wykroczeń - wypełniały swoje zadanie, a dokonana zmiana i wprowadzony art. 190a k.k. stał się jedynie narzędziem do walki z eks-partnerem. Z drugiej strony, art. 190a k.k. może wpływać prewencyjnie na potencjalnych sprawców, którzy dzięki temu powstrzymają się od zachowań prześladowczych. Jednakże nie zawsze sama świadomość karalności czynu spowoduje zmniejszenie liczby popełnianych

40 A. Sakowicz, Opinia prawna o zmianie ustawy - Kodeks karny, http://orka.sejm.gov.pl/IEKSBAS.nsf/0/C1257806 003D0075C1257806003EE8F2/\$file/i2133-10.pdf, dostęp dn. 17.11.2012 r., s. 7.

Ustawa z 4 lutego 1994 r. o prawie autorskim i prawach pokrewnych (Dz.U. z 2006 r. Nr 90, poz. 631 ze zm.).

Uzasadnienie..., op. cit., s. 11.

Ibidem, s. 11.

M. Budyn-Kulik, Kodeks karny..., op. cit., pkt 78. 
przestępstw, zwłaszcza mając to na uwadze w kontekście stalkingu. Uporczywe nękanie jest bowiem rozumiane jako pewien typ uzależnienia, przy czym tym środkiem uzależniającym jest druga osoba. Tak samo jak alkoholikowi trudno przestać nadużywać alkohol, tak samo stalker może nie obawiać się ewentualnych konsekwencji swojego postępowania. Stąd wniosek, iż konieczne jest wcześniejsze poddanie sprawcy terapii psychologicznej i psychiatrycznej.

\section{BIBLIOGRAFIA}

1. Budyn-Kulik M., Kodeks karny. Komentarz do zmian wprowadzonych ustawą z dnia 25 lutego 2011 r. o zmianie ustawy - Kodeks karny, wersja online, Lex.

2. Chlebowska A., Nalewajko P., Stalking - zarys problemu oraz analiza rozwiązań ustawodawcy niemieckiego, austriackiego, polskiego, „Prokurator” 2010/2011, nr 4(44)/1(45).

3. Długosz J., O zasadności kryminalizacji tzw. stalkingu, [w:] Tożsamość polskiego prawa karnego, Pikulski S., Romańczuk-Grocka M., Orłowska-Zielińska B. (red.), Olsztyn 2011.

4. Gruszczyńska B., Marczewski M., Ostaszewski P., Siemaszko A., Woźniakowska-Fajst D., Stalking w Polsce. Rozmiary - Formy - Skutki, [w:] Stosowanie prawa. Księga jubileuszowa z okazji XX-lecia Instytutu Wymiaru Sprawiedliwości, Siemaszko A. (red.), Warszawa 2011.

5. Hołyst B., Psychologia kryminalistyczna, Warszawa 2009.

6. Kosińska J., Prawnokarna problematyka stalkingu, „Prokuratura i Prawo” 2008, nr 10.

7. Mullen P., Pathe M., Purcell R., Stalkers and their victims, Cambridge University Press 2009.

8. Pathe M., Surviving stalking, Cambridge 2002.

9. Piotrowicz D., Chorobliwa miłość, „Psychologia w teatrze życia” 2009, nr 1.

10. Wielki słownik polsko-angielski, Oxford 2002.

11. Woźniak W., Lattanzi M., Stalking - między przemocą a uzależnieniem, Konstantynów ŁódzkiKutno 2010.

12. Woźniakowska-Fajst D., Prawne możliwości walki ze zjawiskiem stalkingu - czy w prawie polskim potrzebna jest penalizacja prześladowania, „Archiwum Kryminologii” 2009, tom XXXI.

13. Ustawa z 4 lutego 1994 r. - o prawie autorskim i prawach pokrewnych (Dz.U. z 2006 r. Nr 90, poz. 631 ze zm.).

14. Ustawa z dnia 6 czerwca 1997 r. - kodeks karny (Dz.U. Nr 88, poz. 553 ze zm.). 


\section{STALKING FROM AN INTERDISCIPLINARY PERSPECTIVE}

Stalking is interdisciplinary phenomenon, and therefore in order to fully understand it, one needs to be equipped with psychological, sociological and criminological background knowledge.

Stalking differs from other crimes in that it usually involves different forms of psychological harassment: threats, following, monitoring, destroying the victim's possessions as well as resorting to the harassment of people close to the victim. Stalkers can make use of different equipment such as cameras, computers, mobile phones, GPS devices and also more specific devices enabling them to hack into someone's computer and gain access to private data. The presented variety of behaviours that stalking usually involves makes it difficult to assess it applying a standard case-based approach. There is also great difficulty in foreseeing all the possible actions the culprit may resort to.

The approach to the phenomenon of stalking has changed. As a result, no longer is a pushy suitor and his advances towards an admired woman treated nor seen as merely a reason for feeling flattered. The right to privacy gives us the freedom of deciding what we want to do and also in principal guarantees that others cannot invade our personal space. Hence, stalking to any degree should not be accepted by the society and law.

Key words: threat, stalker, victim, harassment 